\title{
PEDAGOGICAL CONTENT KNOWLEDGE DEPELOPMENT OF SCIENCE PROSPECTIVE TEACHERS IN PROFESSIONAL PRACTICE PROGRAM
}

\author{
Diana Rochintaniawati ${ }^{\varpi 1}$, Ari Widodo ${ }^{2}$, Riandi $^{3}$, Lina Herlina ${ }^{4}$ \\ ${ }^{1,2}$ International Program on Science Education FPMIPA UPI \\ ${ }^{3}$ Biology Education FMIPA UPI \\ ${ }^{4}$ SMPN 12 Bandung
}

\section{Article Info \\ Received April 2018 Accepted May 2018 \\ Published July 2018 \\ Keywords: \\ Pedagogical content \\ knowledege, prospective science teachers}

\begin{abstract}
The study of "Pedagogical Content Knowledge Development of Science Prospective Teachers in Professional Practice Program" was conducted in one junior high school located in Bandung. The purpose of the study was to analyze the level and pattern of science prospective teachers' PCK development as measured by CoRe. The study involved students who enrolled professionals practice program. Mixed methods, quantitative and qualitative research was utilized as a method in the study. Data collected by the coding and scoring of the CoRe instruments were analyzed quantitatively; and data gained from observation, documentation, and interviews were analyzed qualitatively. The results showed that the PCK of prospective teachers are in the maturing PCK (level 3) and growing PCK (level 2). There are two patterns of PCK development showed by prospective teachers i.e. rising and fluctuative. The prospective teachers who are in the mature PCK show the pattern of rising, whereas prospective teachers who are in the growing PCK show fluctuative pattern. The study reveals that external and internal factors influenced the development of PCK. The pattern of guidance, lesson study activities, and intensity guidance are external factors that influenced the pattern of prospective students' PCK development. Psychological effect that exists between teachers and students, the motivation of self to expand the horizons of knowledge, communication skills, and teaching experiences are the internal factors that influenced the development of prospective teacher PCK. The study suggests that the development of prospective teachers PCK in the program can be improved when supervisor and prospective teachers put consideration to those internal and external factors that influence the development of PCK.
\end{abstract}




\section{INTRODUCTION}

Teacher plays an important role in determining the success of education beside curriculum, and both influence the quality of formal education. Science teaching in Indonesia is considered not yet satisfying as it performed by students' achievement published in international benchmarking in TIMSS and PISA (Chang et al. 2014). One factor that contribute to this situation is teachers' quality (Widodo, 2017). Although Indonesian government has responsded by launching a program of "Teacher Certification", however the result has not yet significanlly improved the quality of science teaching in Indonesia. Chang et al., (2014) and Widodo (20017) claim that certification does not lead to improvement of teachers' teaching performance, teachers' behavior and teachers' participation in teachers' professional development.

One phase that contributes to the quality of teachers is the pre service period. In the pre-service period prospective teachers develop knowledge, views and values that they will be impelemented in their future career (Widodo, 2017). Although there are many studies conducted on pre- service educational program, however studies on prospective teachers PCK is still lack.

Prospective teachers are given content knowledge and pedagogical knowledge in several subjects of content courses and pedagogy courses. Student teachers need to combine these two knowledges in their PCK in several subject i.e school sciences, peer teaching and professional practice program. Professional practice program provides teachers student with the first real teaching situation. In this program they have experience to combine content knowledge and pedagogical knowledge to strengthen their PCK. Loughran et al., (2012) argued that PCK is developed from time to time through experience until they become professionals. Through professional practice program, prospective teachers have experience for 6 moths. Identifying and Analyzing pre-service teachers' PCK development is needed to give feedback to improve the program.

PCK was introduced by Lee Shulman in 1986 (Ball et al., 2008) that identified specific teachers' knowledge domain as it called as knowledge to content domanin. Science teacher has to gain knowledge of learners' sience, curriculum, teaching strategy and assessment in order to do the transformation of science knowledge for enhanching the ability of their PCK. Shulman (1986, in Kartal et al., 2012) stated that PCK is intersectional between content knowledge and pedagogical knowldege. Shing et al (2015) pointed out that PCK is a blending of pedagogy and subject content knowledge. The definition of PCK give meaning that teachers are not only have to master content knowledge but also have to master how to raise students' interest to learn to make them esier to understand the science content.

PCK is a thinking concept which give meaning that to teach science is not only understand the content of science (knowing of science) but also how to teach science. This indicates that knowing of science is important for science teacher but not enough for teaching science. Ball (in Kartal et al., 2012) argued that knowledge of pedagogy put in a second posisition in determining teachers' qualification. Many of study investigate teacher knowledge to the science content. They claimed that teacher cannot teach without their knowledge to the content. Pedagogical knowledge is urgently needed by teacher to carry out effective teaching. Many argues that teaching is a complex process as it involeves many factors that have to be planned effectively. Finlayson et al (1998), suggested that a good Science teacher needs to have good competency, classroom management and strong background knowledge of the subject and studies show that teachers who lack content knowledge face difficulties and do not have confidence in their teaching (Finlayson et al., 1998). Therefore tacher needs to build a harmony system from those to make succeful teaching.

Ball et al. (2001) pointed out mastering content deeply is not enough for the teacher, they also have to understand the conceptual and interrelation of ideas as well as diffulties faced by learners. Magnusson (1999) proposes five aspects of PCK, they are: (1) Science curriculum (objective, direction and approach), (2) students' understanding to the specific science topics, (3) assessmen (what should be assessed and how it assessed), strategy to teach science and orientation of science teaching (conceptual changes of objective, process).

The result of study related PCK showed that one factor which might be use to improve effectivity of teacher in teaching science is developing teachers' PCK (Loughran et al., 
2012). PCK is built simoultaneusy from time to time influenced and it is influenced by experience. PCK is academic idea that provide ideas in raising interest and it develop continuously through experience of how to teach specific content with specific strategy to gain students understanding (Loughran et al., 2012). PCK is an idea rooted from believe that teaching not only transfering information of content to students and learning is not only taking information but more to how it applied in the real situation. PCK is knowledge about what, when, why, and how to teach with using precious knowledge. The PCK is drawn as in Figure 1.

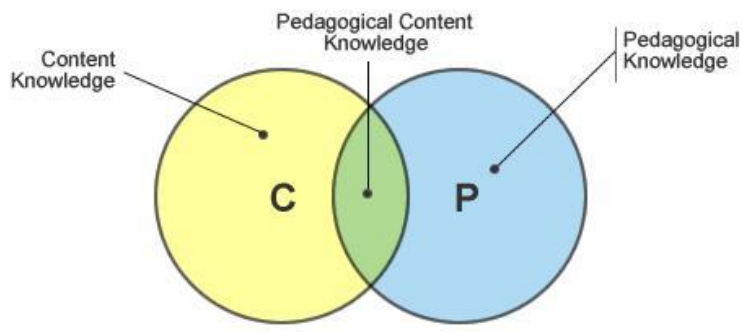

Figure 1. Component of Pedagogical Content Knowledge (adapted from Bowles, 2009)

PCK component includes:

1. Knowledge of teacher as learners

2. Knowledge of Curriculum

3. Knowledge of Instructional strategics for science teaching

4. Knowledge of assessment (Hanuscin et al., 2011)

Shulman (1986, in Koehler, 2011) argued that both content knowledge and pedagogical knowledge are exclusive domain. In order to make different dichotomy of this knowledge, Shulman proposed to consider the relationship that is needed for these two knowledges by intrioducing PCK. The key component of PCK is to understand knowledge, concept and misconception of the learners. PCK can help teacher to interpret and shape learners with effective instruction (Magnusson et al., 1999) in Nuangchalerm, 2011). Shulman (1986, in Van Dijk, 2009) introduced PCK as a knowledge of specific category in a dimension of content knowledge for teaching. The teachers' PCK can be seen by using CoRe dan PaP-eR. CoRe can be used as a methodology to access science teachers' knowledge to the content or subject matter. CoRe is is used to see teachers' understanding to content which are expressed in "big ideas" related with teaching specific content.in a certain level based on their experience.
Teachers play an important role in instructional process; they have to be able to make contiounous innovation in their teahing. Teachers have to control, optimize, and explore their own potential in order to construct good plan for their teaching strategy. The instructional process as a transform of understanding is depend on quality and flexibility of content knowledge and capacity to produce strong representation and reflextion of the knowledge (Shulman \& Grossman, 1989, in Taylor Thoma, 2009). Teachers' PCK is specific skill that correlated with personal speciality which affected by teaching environment. Teachers' PCK within different teachers are different, however PCK is a point where professional knowledge meet the teachers' skill. Thereform, many of study concluded that PCK is knowledge that developed by teachers continuously through their experience on how they teach content in many strategies to have richfulnnes of students' understanding.

There are some reasons why PCK is considered important for teacher. Shulman did research on teachers' knowledge directed to role of content in teaching. PCK then is used to focus general aspects of teaching such as classroom management, time allocation and planning. Diferent thought proposed by Shulman that improving teachers content knowledge as a key to make technically success for teacher as a proffesion, as Shulman points aout that qualified instruction need professional knowledge that follow simple rule such as how long dose teacher has to wait to have students' respond (Ball et al. 2008). Teachers' PCK can be evaluated by using CoRe (Content Representations) and PaP-eRs (Pedagogical and Professional-experience Repertoires) developed by Loughran et al. (2004). Element of CoRe and analysis to CoRe and PaP-eRs shows efectivity of instruction activity that in-line with learning objective.

\section{METHODS}

Mix method is used as a method in the study by using sequential expalanation. The strategy begins with data collection and quantitavely analysis in the first stage, followed by qualitative data gathering and analisys. The process of mix in this study occurred when quantitative data from the first stage inform the process of qualitative data gathering and 
analisys (Creswell, 2010). This study resulted in quantitative data i.e the level of pre-service teacher PCK measured by CoRe. Analysis to the CoRe by using rough statistics gives information of preservice teacher PCK category or the level of PCK and it is compared with students' respond to the teaching. Meanwhile qualitative data that support the quantitative data reveals factors that influence the pattern of prospective teachers PCK development. Univariate analysis was done to only to one variable but to all variables that aimed to get information of the variables in a form of ordinal scale. Qualitative data of this research was gathered from interview of sample that can be use to strengthening univariate data analysis. The research procedure can be seen in Figure 2.

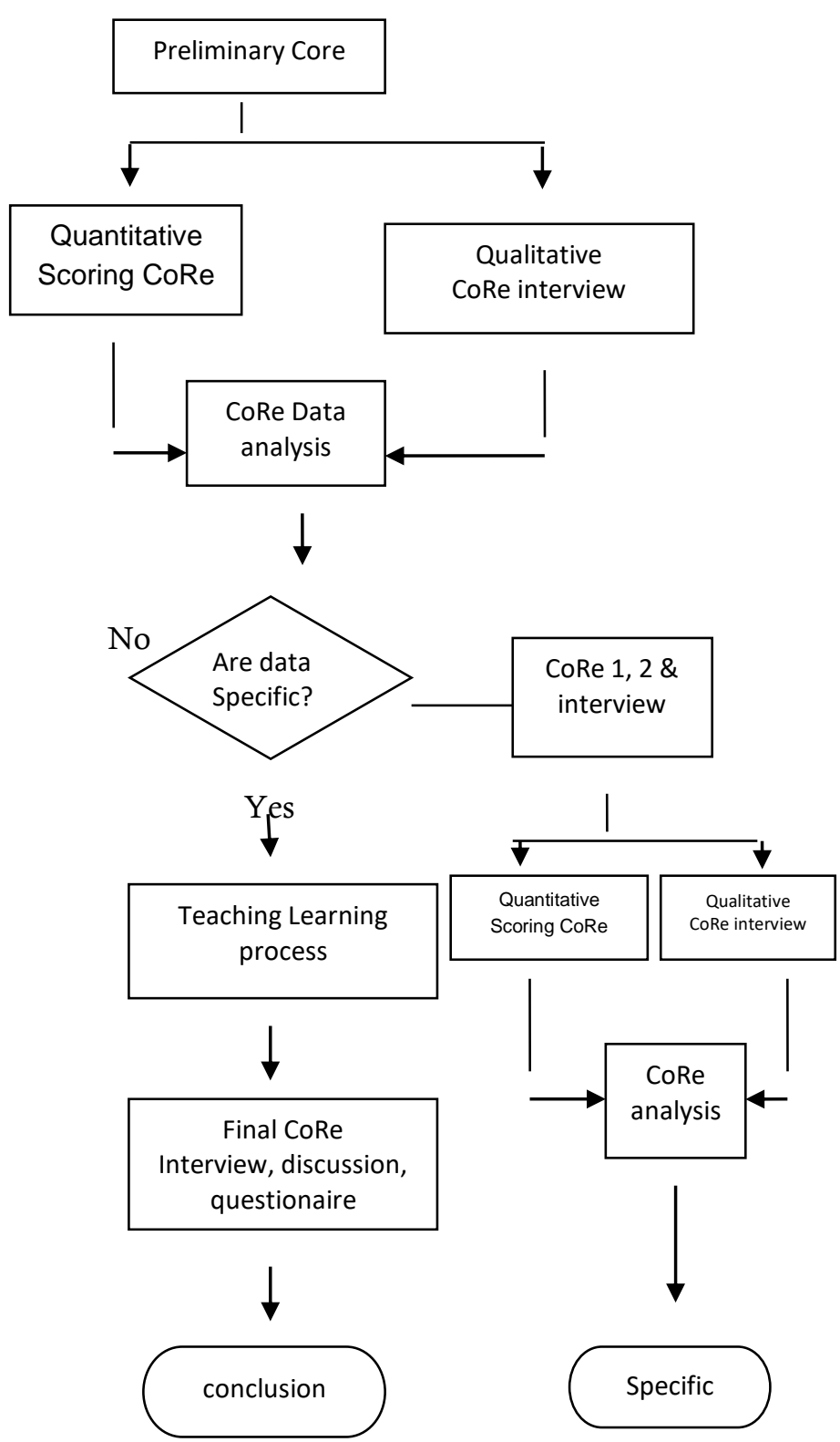

Figure 2. Research Procedure
The research subject involed three prospective teachers enrolled in professional practice program in one Junior High School in Bandung. The first subject is Mrs. $\mathrm{X}$ who has open minded, like to face challenge and friendly; Second subject is Mr. Y who is calm, careful person, and interested on IT; and the third subject is Mrs. Z who is introvert, and has difficulty in communication. Each prospective teacher has to perform for minimum 15 meeting during the program. In this study, we analyze 15 and 16 CoRes of each prospective teacher during their professional practice program. The instrument of research is rubric of CoRe which adopted from Hadiyanti et al. (2014) and interview guidline.

Table 1. Guidline for CoRe Aspect

\begin{tabular}{lll}
\hline No & CoRe Questions & CoRe Aspect \\
\hline 1 & - What will you teach & 1. Teachers' \\
& to students related & knowledge in \\
& to this idea or this & identifiying \\
& concept? & big ideas of \\
& - Why you think it is & the content.
\end{tabular}
important to teach this concept?

\begin{tabular}{|c|c|}
\hline 2 & $\begin{array}{l}\text { What are factors that } 2 \text {. Teacher } \\
\text { might influence your } \begin{array}{l}\text { consideration } \\
\text { consideration in to the specific } \\
\text { teaching this concept? }\end{array} \\
\begin{array}{l}\text { concept that } \\
\text { she } / \text { he choose }\end{array}\end{array}$ \\
\hline 3 & 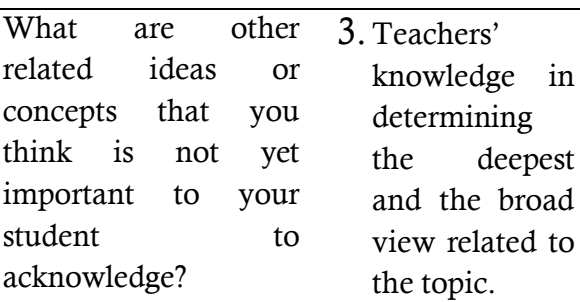 \\
\hline
\end{tabular}

\begin{tabular}{|c|c|c|}
\hline \multirow[t]{9}{*}{4} & - What are difficulties & \multirow{9}{*}{$\begin{array}{l}\text { 4. Teachers' } \\
\text { knowledge in } \\
\text { identifying } \\
\text { students' prior } \\
\text { knowledge and } \\
\text { students' } \\
\text { difficulty in } \\
\text { learning the } \\
\text { concept. }\end{array}$} \\
\hline & that might & \\
\hline & encounter & \\
\hline & teaching & \\
\hline & concept? & \\
\hline & - What are & \\
\hline & misconceptions that & \\
\hline & $\begin{array}{ll}\text { might } & \text { arise from } \\
\text { your student in }\end{array}$ & \\
\hline & $\begin{array}{l}\text { understanding the } \\
\text { concept? }\end{array}$ & \\
\hline
\end{tabular}




\begin{tabular}{|c|c|c|}
\hline 5 & $\begin{array}{l}\text { - How will your } \\
\text { sequence in } \\
\text { teaching } \\
\text { concept? } \\
\text { - How will you use } \\
\text { IT in teaching the } \\
\text { concept? } \\
\text { - How will you take } \\
\text { action when you } \\
\text { find there is no } \\
\text { media provide by } \\
\text { your school to teach } \\
\text { the concept? }\end{array}$ & $\begin{array}{l}\text { 5. Teachers' } \\
\text { consideration } \\
\text { in choosing } \\
\text { teaching } \\
\text { strategy. }\end{array}$ \\
\hline 6 & $\begin{array}{l}\text { How will you know } \\
\text { if your students } \\
\text { have master the } \\
\text { concept? }\end{array}$ & $\begin{array}{l}\text { 6. Teachers' } \\
\text { knowledge in } \\
\text { assessment of } \\
\text { learning. }\end{array}$ \\
\hline
\end{tabular}

Source: Adopted from Hadiyanti et al. (2014)

The data that has been classified by CoRe aspect is then analyzed by using rubric CoRe to detemin score and make categorization of the PCK based on the level. Categorization of the PCK can be seen in Table 2 .

Table 2. Category for PCK

\begin{tabular}{lll}
\hline No & CoRe score & Category \\
\hline 1 & $0-33$ & Pre PCK (Level 1) \\
\hline 2 & $34-67$ & Growing PCK (Level 2) \\
\hline 3 & $68-100$ & $\begin{array}{l}\text { Maturing PCK (Level } \\
3)\end{array}$ \\
\hline
\end{tabular}

\section{RESULT AND DISCUSSION}

CoRe is used as it can help beginner teacher to gain acess to the knowledge and experience as good as experienced teachers (Earnes et al., 2012). The study based on analysis to the CoRe resulted in two prospective teacres (Mrs. X and Mr.Y) are in the level of maturing PCK or are in the level 3, and Mrs. $\mathrm{Z}$ is in Growing PCK or in a level 2.

The patterns of prospective teachers CoRes' developments are as follow: Mrs.X and Mr.Y showed the increasing pattern of their CoRe, and Mrs.Z showed the fluctuation pattern during the program. Figure 1, 2 and 3 show the development patten of Mrs. X PCK in 15 meeting, Mr. Y PCK in 16 meeting and Mrs. $\mathrm{Z}$ in 16 meeting respectively.

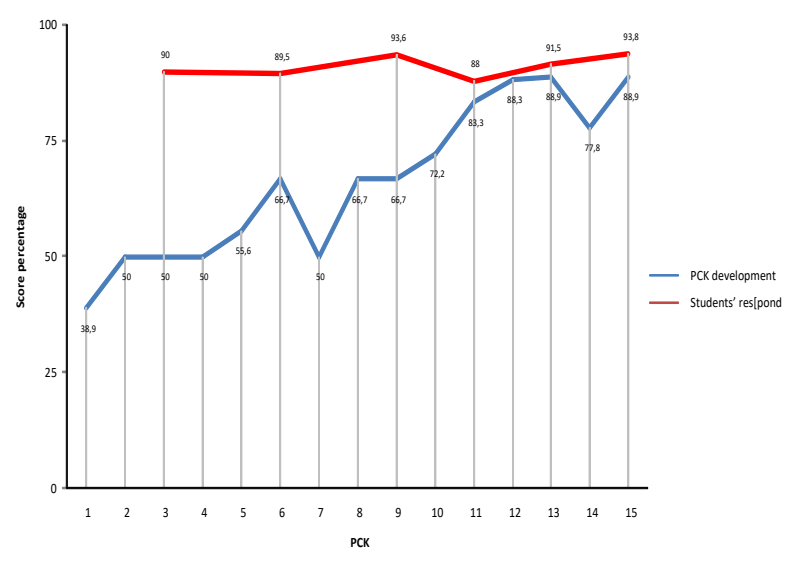

Figure 3. Development of PCK from Mrs.X in in 15 meeting compared with students' respond to the teaching

Figure 3 shows the improvement of Mrs. X PCK from pre PCK to maturing PCK in 15 meeting. The development of Mrs X PCK in the early stage showed fluctruated pattern in pre PCK to growing PCK, however her PCK can be improve to the maturing $\mathrm{PCK}$ after eleven meeting. Mrs X consistenly maintains her PCK developmet in maturing PCK until the last meeting. Although the graph shows there is a drop of Mrs. X PCK in 14 meeting but her PCK it still in the category of maturing PCK. The students respond positively to her teaching from her initial teaching. The character of open minded supported Mrs. X to perform well in her teaching. She also can take the chance of her teaching as a challenging and able to use time efficiently to communicate with supervisors, collegues and students. In conclusion, the result of Mrs. X PCK is in the level 3.

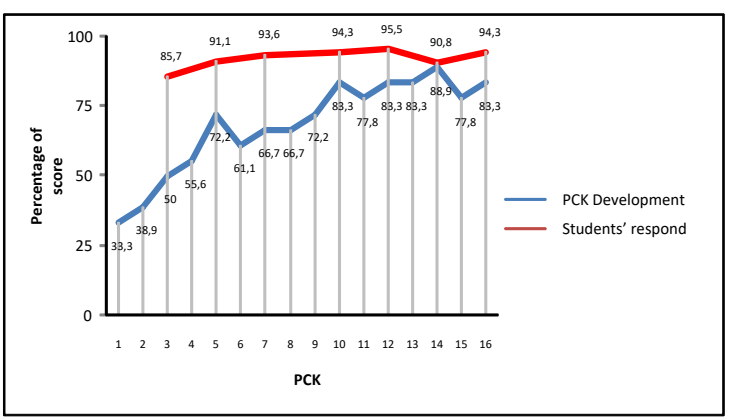

Figure 4. Development of PCK from Mr.Y in 16 meeting compared with students' respond to the teaching

Figure 4 shows the improvement of Mr.Y PCK from pre PCK to growing PCK in the fift meeting. Mr.Y showed better PCK 
improvement comparing Mrs.X and have more stabil pattern of PCK development. He can reach the level of maturing PCK in the tenth meeting until the end of the program. His ability to use IT supported Mr. Y to present interesting teaching that give positive respond throughout his teaching. Similar with Mrr. X, Mr. Y PCK is in level 3.

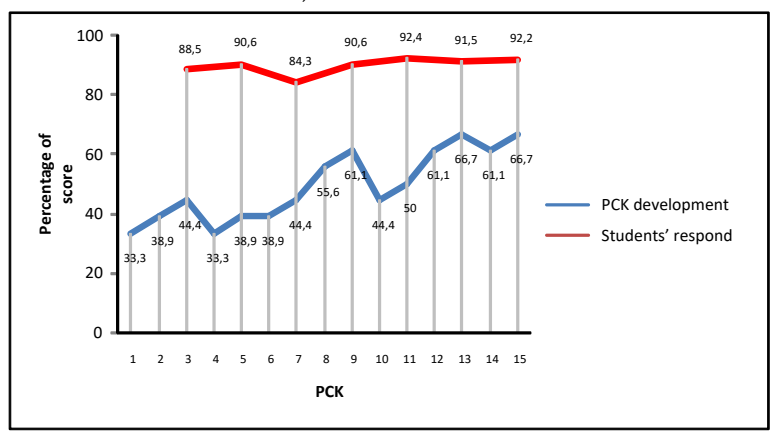

Figure 5. Development of PCK from Mrs.Z in the concept of Living Thing Classification and students' respond to Mrs.Z teaching in seven meeting

Figure 5 shows Mrs.Z PCK improvement from pre $\mathrm{PCK}$ to growing $\mathrm{PCK}$ in the ninth meeting. However her PCK development pattern was fluctuated. In the $10^{\text {th }}$ and $11^{\text {th }}$ PCK she performed decreseasing of her PCK. Until the end of the program, Mrs. $Z$ stayed in growing PCK and never reached the mature PCK. Therefore her PCK is in a level 2. Although students responded positively to Mrs. $\mathrm{Z}$ teaching since from the beginning of her performance, however the Graph 1, 2 and 3 show that students more responded positively to teacher teaching inline with the increasing of their PCK.

\section{DISCUSSION}

The study resulted in two pattern of PCK development, improving pattern and fluctuative pattern. The increasing pattern means that all CoRe aspect thas has been measured tend to improve, started from pre PCK category (level 1), to growing PCK category (level 2), and end up in maturing PCK category (level 3). Fluctuated pattern of PCK development showed increasing and decreasing of PCK during the program. Qualitative data gain from interview reavelas the factors that influence these pattern, they are external factors and internal factors. The external factor that influences to the result are: 1) pattern of guidance supervison, 2) lesson study; and 3) intensity of supervision. Internal factor that involved to the result of the study are: 1) psichologycal approach, 2) self motivation 3) communication skill, and 4) teaching experience. Teacher can have and manipulated both internal and external factors. This finding is different with what Hadiyanti (2014) found that factor which might influence teachers' PCK development are more to the expernal factors, they are: 1) time allocation and curriculum 2) Class condition 3) students' prior knowledge, experience and environment when teaching learning occurred, 4) choosing the concept, 5) technic and teaching media, 6) content and 7) students willingness to study.

The study from Rusmana (2014), give less information of the aspect that influence to the PCK development, they are: 1) students' motivation, 2) students' understanding to the IT, 3) facility and 4) teacher content knowledge. The result of this research related to the factors that influence prospective teachers' PCK development is more tho the internal aspects. Shulman (1986) introduce PCK as specific category to the dimensions of knowledge for teaching which includes: (1) content knowledge, (2) pedadogycal knowledge, (3)knowledge to the curriculum, (4) Pedagogical content knowledge, (5) knowledge of learners and their characteristics, (6) knowledge of educational context, (7) knowledge to the aim, goal, objectives of education, value, philosophy and historical. (Shulman, 1987 in Nuangchalerm, 2011 and Van Dijk, 2009). Based on previous description it can be concluded that development of PCK is tend to the knowledge of the content.

PCK is academic ideas which provide ideas raising continous motivation from experience of how to teach certain content through specific strategy to gain students' understanding (Loughran et al., 2012). PCK can be developed from teachers' experience in teaching learning process from time to time, therefore PCK development can not be ended in one point of time.aspect that relatied to the motivation can increase or decrease at any time, and this also happening to the PCK development. The pettern of development is determined by mental condition of the teacher or prospective teacher.

There are several factors that influence PCK development of prospective teachers in the program of professional teching shown in this study. Those factors are divided into external factors and internal factors. 


\section{External Factor}

\section{a. Supervision Pattern}

Supervision pattern given by supervisor during the program of professional teaching is utilized differently by three prospective teachers. Mrs X, who is more open minded frequently ask questions that other if she face difficulty in her teaching. Mrs $\mathrm{X}$ is also well prepared for her teaching by asking suggestion for her lesson plan before she uses it in her teaching. Therefore her teaching was carriod out based on supervisor advised. Mrs. X intensively communicates with her supervisor in or outside of her schedule.

Mr. Y tend to have himself find out solution for his problem related to his teaching by using internet access, before he consult supervisor. $\mathrm{He}$ construct lesson plan after he study the content from browsing the internet. He was also eager in taking experiment of his supervisor advice for his teaching related to classroom management, methos of teaching, as well as media for his teaching. However he mostly cannot put the administration for his teaching in a date time. Mr. $\mathrm{Y}$ is actively communicate with his supervisor by sending message via phone or e-mail rather that direct communication.

Mrs. $\mathrm{Z}$ is passively did the supervision with her supervisor. She did the supervision only on the teaching schedule. Recommendation and suggestion from the supervisor frequently ignored and she did the teaching process based on her point of view. She also rarely asked question and recommendation from supervisor related to her teaching practice.

Based on the finding above, the pattern of supervision is closely realated to the improvement of PCK. Prospective teachers can utilize supervision as a source to improve their PCK. This is proven by behavior showed by two respondends, Mrs. $\mathrm{X}$ and Mr. Y who utilize maximally the process of supervision. As a consequence, they produce better construction of lesson plan for their teaching. On the other hand, Mrs. Z did not utilize supervision program as good as Mrs. $\mathrm{X}$ and $\mathrm{Mr}$. Z, therefore her PCK improvement was not good as the two respondents. The supervision program is urgent for prosfective teachers as they have fewer experiences in teaching. The supervisor experience can be use as an access for prospective teachers to develop big ideas of the content that they will teach. The involvement of expert in the process of supervision can influence prospective teachers in developing their CoRes (Eames et al., 2011).

\section{b. Lesson Study Activities}

Mrs. $\mathrm{X}$ is more an anthusiatics when her teaching was supervised by her supervisor and her friends. She always prepared her teaching with good planning in order to show others her best teaching. In the process of reflection Mrs X was welcome to take advises for her next teaching from her supervisor and from her collegues. Suggestion from her supervisor and colegues was use to improve a better planning for her next teaching.

Mr. Y was a self confidence person. He put comment or his teaching before other give suggestions for his teaching. His ability of self reflection made his PCK improve very well. Mrs. $Z$ was lack confidence person and it can be seen when her supervisor and her friends made observation to her teaching by showing nervous. She also frequently refused for being observed if she feel not ready with her teaching. With her weakness, the activity of lesson study to Mrs. Z was carried out when she said she was confidence for being observed. In the reflection stage, she was opend minded to accept other suggestions; however it did not utilize to improve her next teaching.

Based on this finding, it can be concludes that lesson study can be used to make correction for the teaching mistakes or weakness. The most important from lesson study activity is when the respondend utilize reflection to improve the next better teaching. In Lesson study reflection from other is proven to be more efficient compared with self relection. Suryani et al., (2010) argued that Lesson Study give contribution to: 1) improve teachers' conception of the teaching, 2) improve ability in developing set of teaching, and 3) improve teacher capability in teaching

\section{c. Intensity of Supervision}

Mrs. X and Mr. Y did the supervison more intensively compared with Mrs. Z. They both make comunication with their supervisor not only on the teaching schedule but also out of teaching schedule. They also utilize IT (handphone and email) to communicate with their supervisor. On the other hand Mrs. Z has supervision only on her teaching schedule. She rarely asked for the advice by using phone or email. In concusion, the more prospective make communication with their supervisor, the more 
knowledge they gain, as a consequence the faster they will improve their PCK.

\section{Internal Factors}

a. Psychological Effect from Relationship Between Prospective Teachers and Students.

Three prospective teachers showed different strategy to make them close with their students. Mrs $\mathrm{X}$, often give joke in her teaching that make students were feels happy during the process of teaching. Mr. $Y$ frequently use games that entertain students in his teaching, meanwhile Mrs. Z approach students out of her teaching schedule to make student close with her. The strategy that showed by three prospective teachers aim to understand students' characteristic in order to run smoth teaching process.

Psychological effect is closely realated with instinc and psychoanalytic. These two factors wil bring somenone to change pattern thinking to do as his/her instinc. Atkinson, et al., (2008) argues both psychoanalytic theory and instinc theory influence the cange of conception from rational view to motivational view. Asrori (2007) stated that the involvement of emotion in teaching process influence teachers psychological effect that might contribute to the development of PCK of prospective teachers. Finding in this reaserach showed that three prospective teachers did not have obstacle to understand stundents characteristics.

\section{b. Self Motivation to Improve Knowledge}

Mrs. X was motivated teacher that always find herself to improve her knowledge. She used students' questions that she cannot answer to motivate herself to learn more about the topic. She learned curriculum, books and other relevant sources in order to find out the answer. Before she did the teaching she frequently made prediction on questions that might be posed by students and she made answer for her prediction questions. Mr. Y used internet as mostly source of his teaching beside teaxtbook. Mr. Y spent longer time at school to browse refferences in internet to improve his knowledge. He also ulitized laboratory as a source of his teaching with trying several experiment and exploring to the teaching media provided in lab. His attractions to the wider content become his motivation in his teaching.

Behaviour form three prospective teachers showed their motivation in effort of gaining more knowledge to the content they teach.The three prospective teachers use different strategy to gain more knowledge. Motivation is one important aspect in achieveing the goal. Hobes (in Atkinson, et al., 2008) stated that human behavior tend to find something that can make him hapy and avoid challenge. Maslow (in Asrori, 2007) argue that someone is motivated because she/he has needs that have to be fulfilled. Gaining more knowledge is one of teachers' needs that will bring him/her to the satisfaction in his/her teaching. This relationship will effect ti the imperovement of teachers' PCK.

\section{c. Communication Skill}

Mrs. $\mathrm{X}$ and Mr. Y showed better communication compared with Mrs. Z. Communication between Mrs. X and Mr. Y with her/his students run in two ways communication. Mrs. $\mathrm{Z}$ has difficulty in communication with her students. Sometimes she cannot understand students' questions. Mrs. $\mathrm{Z}$ has difficulty in communication as she comes from different province. Therefore Mrs. Z sometimes cannot respond to the students' questions. Asrori (2007) pointed out that manifestation of thinking process is a language. Moreover he also pointed out that thiking ability can be seen from the language, and language ability is a mirror of thnking ability. In conclusion communication contributes to the prospective teachers PCK development.

\section{d. Teaching Experience}

The three prosfective teachers have similar range of time in doing their professionals teaching. The difference is how they can use the time to evaluate their teaching. Mrs. X and Mr. $\mathrm{Y}$ are faster learners; they learn from other reflection and make self analysis of their teching. This action made their learning experience become more meaningful than Mrs. Z. as a result PCK of Mrs. X and Mr. Y are more improved compared with Mrs. Z PCK. Lougharn (2012) stated that PCK is academic ideas which provide motivational and continous ideas though experience of how to teach content in order to achieve the goal. CoRe is developed to find out of what teachers' think about big idea related to the taching of specific topic in certain level based on teachers experience in teaching the topic. Adams dan Krockover (1997, in Van Driel et al., 1997) studied the improvement of 
early PCK from beginner science teacher and found out that knowledge of good instructional startaegy comes from experience when they were a students, assistant of teacher or experienced teacher. Therefore it can be concluded that experience influence PCK improvement.

\section{CONCLUSION}

The study resulted in the finding that Mrs $\mathrm{X}$ and $\mathrm{Mr}$. Y are in the category of maturing PCK or in level 3 and Mrs. $Z$ is in the category of growing PCK or in level 2. The pattern of Mrs. X and Mr. Y PCK development tend to increas and Mrs. Z showed the fluctutive pattern. Students showed positive respond to the three prospective teachers' teaching since the beginning of their teaching and showed better respond in line with the improvement of their PCK. Factors that influence the development of prospective teachers PCK are external factors and internal factors. The pattern of supervision; lesson study; and intensity of supervision are expernal factor that influence prospective teachers' PCK development. Relationship between teacher and students; self motivation to gain more knowledge; communication ability and teaching experience are the internal factor which influences the PCK development of prospective teachers. There are several obstacles which related to the PCK development, they are: 1) lack of self confidence in the activity of lesson study, 2) cannot utilize the time for supervision, 3) lack of refferences, opportunity, finance and physicly ability of prospective teaaher and 4) lack of understanding the language that make obstacle in communication. The study suggests that the development of prospective teachers PCK in the program can be improved when supervisor and prospective teachers put consideration to those internal and external factors that influence the development of PCK.

\section{REFFERENCES}

Asrori, M. (2007). Psikologi Pembelajaran. Bandung: Wacana Prima. Cetakan pertama.

Atkinson, Rita, Atkinson, Richard. And Hilgard, Ernest (2008). Pengantar Psikologi. Jakarta: Erlangga. Edisi kedelapan, Jilid 2

Ball, D. L., Thames, M. H., \& Phelps, G. (2008). Content knowledge for teaching: What makes it special? Journal of Teacher Education, 59 (5), 389-407.
Ball, D. L., Lubienski, S. T., \& Mewborn, D. S. (2001). Research on teaching mathematics: The unsolved problem of teachers' mathematical knowledge. In V. Richardson (Ed.), Handbook of research on teaching (4th ed., pp. 433-456). New York, NY: Macmillan

Bowles, F. A. (2009). Learning flourishes when pedagogy merges with content knowledge. in http://www.corndancer.com/vox/gnosis/ artcls 037054/gno now038.html

Chang, Mae Chu; Al-Samarrai, Samer; Ragatz, Andrew B.; Shaeffer, Sheldon;Stevenson, Ritchie; De Ree, Joppe Jaitze. ( 2014). Teacher reform in Indonesia: The roles of politics and evidence in policy making. Washington DC: The World Bank

Creswell, J. W., \& Creswell, J. D. (2017). Research design: Qualitative, quantitative, and mixed methods approaches. Sage publications

Eames, C., Williams, J., Hume, A., \& Lockley, J. (2011). CoRe: A way to build pedagogical content knowledge for beginning teachers. Wellington: Teaching and Learning Research Initiative.

Finlayson, H., Lock, R., Soares, A., \& Tebbutt, M. (1998). Are we producing teaching technicians or Science educators? The consequences of differential demands on trainee Science teachers. Educational Review, 50(1), 45-54.

Hanuscin, Deborah L. Menon, Deepika. Lee, Eun Ju. Cite, Suleyman. (2011). Developing PCK for teaching teachers through a mentored internship in teacher professional development. Paper presented at the 2011 meeting of the Association for Science Teacher Education

Suryani, Sri. Fatimah,Siti. Purwanto, Agus. Suratno, Tatang. (2010). Mengkaji Pengajaran Konsep Perpindahan Panas di Kelas VI SD: Pengelaman Implementasi Lesson Study di Sekolah Avicenna. Second International Seminar 2010. Indonesia University Of Education, 2, Issn. 2086-8340, 189-197.

Kartal, T., Ozturk, N. \& Ekici, G. (2012). Developing pedagogical content knowledge in preservice science teachers through microteaching lesson study. Jurnal: Procedia-Social and Behavioral Sciences: 
Kumpulan jurnal oleh Elsevier Ltd., 46, 27532758.

Koehler, M. (2011). Pedagogical content knowledge (Artikel). Diakses tanggal: 16 September 2014. Dari: http://mkoehler.educ.msu.edu/ tpack/pedagogical-content-knowledge-pck.

Loughran, John; Mulhall, Pamela; Berry, Amanda. (2004). In search of pedagogical content knowledge in science: Developing ways of articulating and documenting professional practice. Journal of Research in Science Teaching, 41 (4). 370-391)

Loughran, John; Mulhall, Pamela; Berry, Amanda. (2012). Understanding and developing science teachers' pedagogical content knowledge. Clayton: Monash University.

Magnusson S, Krajcik J and Borko H (1999). Nature, sources and development of pedagogical content knowledge for science teaching. In $\mathrm{J}$ Gess-Newsome and $\mathrm{N} G$ Lederman (Eds.) PCK and Science Education. Netherlands: Kluwer Academic Publishers. pp 95-132

Nuangchalerm, P. (2011). In-service science teachers' pedagogical content knowledge. Jurnal CSCanada studies in sociology of science, 2 (2), 22-37.

Shing, Chien Lee, Saat Rohaida, Loke, Slow Heng (2015). The Knowledge of Teaching Pedagogical Content Knowledge (PCK). The Malaysian Online Journal of Educational Science, 3 (3), 40-55.

Shulman, Lee S. (1986). Those Who Understand: Knowledge Growth in Teaching. Educational Researcher, 15 (2), 4-14.

Taylor, Thoma. (2009). The elements and applications of pedagogical content knowledge. Artikel International Foundation for Electoral Systems. In: http://www.ifes.org/sitecore/shell/ Controls/Rich\%20Text\%20Editor/ /media

Van Dijk, E. M. (2009). Pedagogical content knowledge in sight? A comment on Kansanen. Jurnal Orbis Scholae, 3 (2), 19-26.

Van Driel, J. H., Verloop, N. dan De Vos, W. (1997). Developing science teachers' pedagogical content knowledge. Journal: Research In Science Teaching, 35 (6), 673-695.

Hadiyanti, Luthfia; Widodo, Ari; Rochintaniawati, Diana, Riandi. (2014). Pedagogical Content
Knowledge of Experienced and Prospective Biology Teachers. Paper: Presneted in UPI UPSI Confrence.

Widodo, A. (2017). Teacher Pedagogical Content Knowledge (PCK) and Students' Reasoning and Wellbeing. Journal of Physics: Conf. Series 812 (2017) 012119. IOP Publishing 